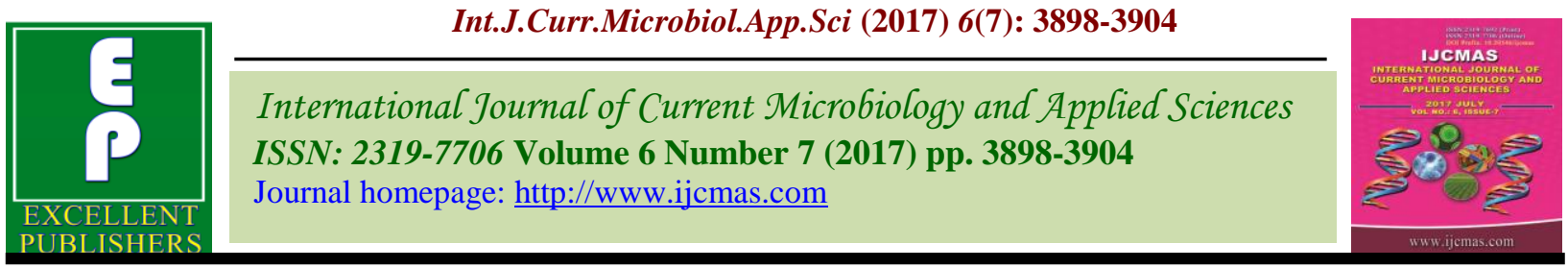

Original Research Article https://doi.org/10.20546/ijcmas.2017.607.402

\title{
Antioxidant Potential of Traditional Rajasthani Chilli Garlic Chutney and its Shelf Life
}

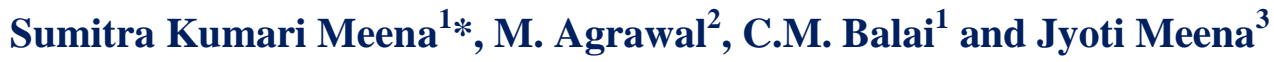 \\ ${ }^{1}$ Krishi Vigyan Kendra, Dungarpur, Rajasthan 314001, India \\ ${ }^{2}$ Department of Home Science, University of Rajasthan, Jaipur 302004, India \\ ${ }^{3}$ Home Science Department, Jai Narayan Vyas University, Jodhpur, Rajasthan, India \\ *Corresponding author
}

\begin{tabular}{|c|c|}
\hline \multicolumn{2}{|r|}{ A B S T R A C T } \\
\hline & \multirow{10}{*}{$\begin{array}{l}\text { Chilli garlic chutney is widely consumed by rural community in Rajasthan state. } \\
\text { Chilli garlic chutney is made from dry red chilli, garlic, coriander seeds, and } \\
\text { tomato with the addition of salt and water for taste. The prepared chutney was } \\
\text { assessed for its antioxidant potential in its raw ingredients as well as in prepared } \\
\text { product. Chutney was stored for } 30 \text { days in deep freezing conditions }\left(0^{0} \mathrm{C}\right) \text { for } \\
\text { shelf life study. The ingredients as well as chilli garlic chutney was found very } \\
\text { rich source of vitamin E, } \beta \text {-carotene, flavonoids and Vitamin C, with good } \\
\text { antioxidant activity. The shelf life study of the chilli garlic chutney indicated that } \\
\text { sensory and nutrition quality was found in decreasing manner with increasing the } \\
\text { storage duration, but still the chutney was showed sensory scores above } 3 \text { till } 30 \\
\text { days of storage and nutrition quality was also found in good retention till } 30 \text { days } \\
\text { of storage. Total bacterial count in freshly prepared chutney was } 0.421 \times 10^{4} \pm 5.57 \\
\text { while total fungal count was } 0.98 \times 10^{2} \pm 5.56 \text {. Total bacterial as well as fungal } \\
\text { count decreased due to storage of chutney. }\end{array}$} \\
\hline Keywords & \\
\hline Chu & \\
\hline $\begin{array}{l}\text { Antioxidant, } \\
\text { Sensory quality, }\end{array}$ & \\
\hline & \\
\hline & \\
\hline Article Info & \\
\hline $\begin{array}{l}\text { Accepted: } \\
\text { 29 June } 2017\end{array}$ & \\
\hline & \\
\hline & \\
\hline
\end{tabular}

\section{Introduction}

Oxidation is a necessary evil, which is essential for biological energy production in most of the living organism, but excessive reactive oxygen species are the main cause of some of the most critical diseases (Oboh et al., 2010). Antioxidants can terminate oxidative chain reactions by removing free radical intermediates and inhibit other oxidation reactions. Antioxidant compounds in food play important roles as health protecting factors. The predominant dietary antioxidants are $\alpha$ tocopherol, $\beta$ carotene, ascorbic acid, phenols and flavonoids. These dietary antioxidants provide an effective defense mechanism against oxidation; hence their presence in the diet helps in the prevention of degenerative diseases. Spices such as dry red chillies, garlic and coriander seeds posses strong antioxidant and antimicrobial properties, due to presence of antioxidant contents such as vitamin $\mathrm{E}$, Vitamin C, $\beta$ carotene, flavonoids and phenolics. Spices and some herbs have received increased attention as sources of many effective antioxidants. Chutney is a term applied to a variety of spicy relishes and 
condiment in Indian cookery and it is eaten as a side dish along with the main course or snacks depending upon the taste. Chutney styles are strikingly different in various parts of the country and among different religious groups. The various flavors and textures are of special importance to Hindus. Chilli garlic chutney is widely consumed by rural community in Rajasthan. In the earlier periods chutney was hand grinded with the help of stones (silbutta) and wood. In modern times machine operated blenders and mixtures have taken over the old silbutta, yet the taste of the old style is still cherished. The rural community of Rajasthan very frequently consume chilli garlic chutney which is basically made from dry red chilli, garlic, coriander seeds, and sour buttermilk with the addition of salt for taste. Dried chilli is a spice product and the most widely used as condiments for flavouring and colouring in Asian cuisines (Jitbunjerdkul and Kijroongrojana, 2007; Toontom et al., 2010) and it is a rich source of vitamin $E$, total phenol and good source of flavonoids, which of late have aroused great interest owing to their antioxidant activities (Ruanma et al., 2010). Garlic (Allium sativum Linn.) and coriander seeds (Coriandrum sativum) are widely used spices which are aromatic and pungent food ingredients. Coriander seed are good source of phenols (Wangensteen et al., 2004) and the antioxidant activity of garlic has mainly been attributed to a variety of sulphur containing compounds and their precursors (Nuutila et al., 2003). In the present study the sour buttermilk was replaced with tomato to improve its antioxidant potential and then quality of the product and its shelf life was assessed in terms of sensory quality, microbial quality and nutritional quality.

\section{Materials and Methods}

Analysis of antioxidants and antioxidant activity in raw ingredients of chilli garlic chutney

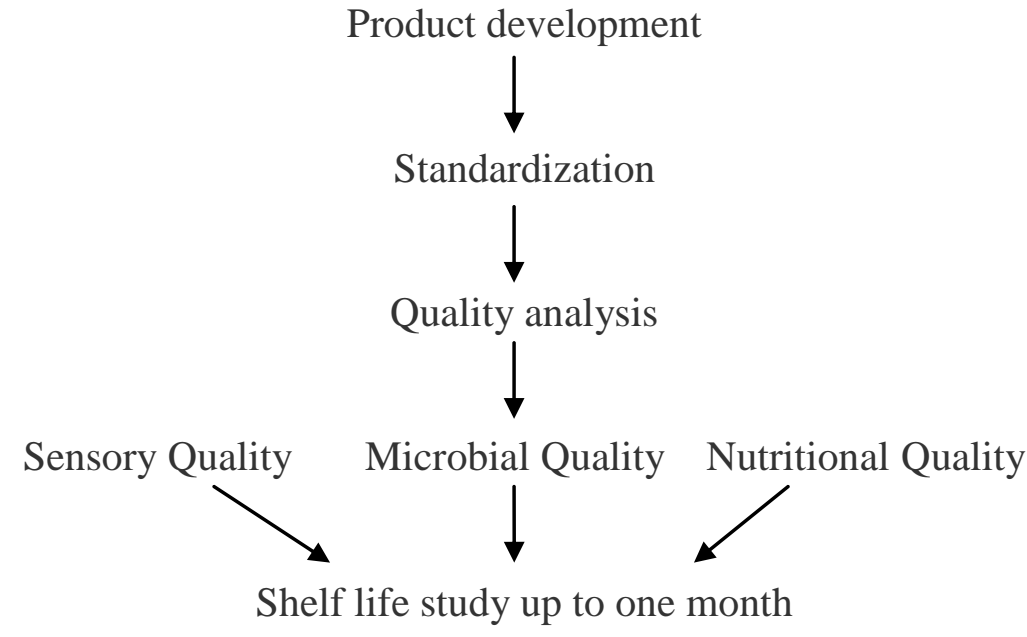

\section{Product development}

The raw ingredients for preparation of chutney i.e. tomato, dry red chillies, garlic, coriander seeds, water and salt were used in the ratio of $60: 11: 9: 7: 10: 3$ respectively. The product was developed by soaking dry red chillies in warm water for half an hour. Water was drained and chilies were collected. The red chilies were ground with garlic, coriander seed and tomatoes to a fine paste and salt was added. Required amount of water was added to obtain correct consistency. A number of permutations and combinations were tried out to develop the product. Necessary alterations have been done and this process was repeated 
till a composition most acceptable by judges was reached. The most acceptable trial of the product found after sensory analysis was then standardized till consistently acceptable results were obtained.

\section{Quality analysis}

\section{Sensory quality}

The product was evaluated for sensory quality using a penal of 10 experts selected through threshold method and trained using triangle method. Sensory evaluation was done to find the acceptability of the product on the basis of composite score test with the sensory attributes viz colour, consistency, appearance, taste, flavour and overall acceptability.

The scores were categorized as 1- poor, 2satisfactory, 3- good, 4- very good, 5excellent. On the basis of acceptability, familiarity of the product the same recipe was prepared in bulk and packed in sterilized zip lock plastic bags and stored in deep freezing conditions $\left(0^{\circ} \mathrm{C}\right)$ till analysis were performed.

\section{Nutritional quality}

Raw material as well as prepared chutney was analysed for vitamin E (Rachieru et al., 2009), vitamin C (Mitic et al., 2011) and $\beta$ carotene (Ahamad et al., 2007) through high performance liquid chromatography (HPLC) methods.

Total flavonoids were assessed in the methenolic extracts of the samples by UV spectrophotometric method suggested by Chandra et al., (2014) and expressed as mg quarcetin equallent (QE)/100g. The antioxidant activity in methenolic extraction of samples in terms of per cent inhibition of free radicals was estimated using 2, 2 dipheny-1-picrylhydrazyl (DPPH) method given by Mandal and Ghosal (2012).

\section{Microbial quality}

Total bacterial count and total fungal count were assessed using standard method suggested by Silliker (1963) and expressed as $\mathrm{CFU} / \mathrm{g}$.

\section{Shelf life study}

To check the shelf life of the standardized product the chilli garlic chutney was prepared in a lot and divided into $10 \mathrm{~g}$ portions and packed into zip lock bags and stored in deep freezing conditions $\left(0^{0} \mathrm{C}\right)$. The products were again analyzed for all the parameters after 15 and 30 day of storage.

\section{Statistical analysis}

Data were tabulated mean and standard deviations were calculated for univariate analysis. One way analysis of variance (ANOVA) was used to analyze the difference in the values obtained at different time intervals.

\section{Results and Discussion}

\section{Quality of the product}

\section{Sensory quality}

The mean scores of fresh product for sensory attributes colour, consistency, appearance, taste, flavour and overall acceptability were $4.46 \pm 0.20,4.73 \pm 0.17,4.50 \pm 0.18,4.75 \pm 0.15$, $4.58 \pm 0.20$ and $4.71 \pm 0.21$, respectively (Table $1)$. The scores obtained above 4 indicated that the product was between very good and excellent quality. Earlier, in the other studies the modified dry fruit chutney evaluated for sensory analysis revealed that chutney was found acceptable and scored between 4 to 5 for all sensory attributes (Shah and Sengupta, 2014). 
Nutritional quality: as assessed by antioxidant contents and antioxidant activity in raw ingredients and in fresh product

\section{Ingredients}

Results revealed that all the ingredients had good amount of dietary antioxidants however dry red chilli was found to be richest source of all the estimated dietary antioxidants. The antioxidant activity in terms of per cent inhibition of free radicals was highest (66.48 $\pm 1.29)$ in coriander seeds and lowest was $(18.68 \pm 1.48)$ in garlic.

Dry red chilli was a found to be rich in vitamin $\mathrm{E}(34.25 \pm 1.59 \mathrm{mg} / 100 \mathrm{~g})$, vitamin $\mathrm{C}$ $(123.53 \pm 1.00 \mathrm{mg} / 100 \mathrm{~g}), \beta$ carotene $(6.18 \pm$ $0.24 \mathrm{mg} / 100 \mathrm{~g})$ and flavonoid content $(1902.40$ $\pm 1.95 \mathrm{mg}$ QE/100g) (Table 2) similarly, Juarez et al., (2012) estimated antioxidant content in five varieties of fresh pepper and found phenolics 59.34mgGAE/100g to 154.30mgGAE/100g. Vitamin $\mathrm{C}$ ranged from 121.14 to $251.60 \mathrm{mg} / 100 \mathrm{~g}$ and flavonoid content was between 25.38 to $60.36 \mathrm{mgQE} / 100 \mathrm{~g}$. Garlic contained good amount of vitamin C. Coriander seeds contribute to flavonoid content (1730 \pm $13.52 \mathrm{mg} \mathrm{QE} / 100 \mathrm{~g}$ ) and antioxidant activity (66.48 \pm 1.29$)$ per cent inhibition (Table 2). Wangensteen et al., (2004) also revealed that coriander seed are good source of phenols. Tomato also contributes to vitamin C (168.27 $\pm 2.34 \mathrm{mg} / 100 \mathrm{~g})$ and flavonoid content (850 \pm $7.55 \mathrm{mg}$ QE/ $100 \mathrm{~g}$ ) with the antioxidant activity (65.38 $\pm 1.35 \%)$. Toor and Savage, (2006) also analyzed antioxidant contents in fresh and dried tomatoes of three verities they found total flavonoids $197-211 \mathrm{mg} \mathrm{RE} / 100 \mathrm{~g}$ in fresh samples and 176-183 $\mathrm{mgRE} / 100 \mathrm{~g}$ in dried samples whereas vitamin $\mathrm{C}$ content was $247-310 \mathrm{mg} / 100 \mathrm{~g}$ and 202-246 $\mathrm{mg} / 100 \mathrm{~g}$ in fresh and dried samples of tomatoes, respectively.

\section{Fresh product}

The standardized chilli garlic chutney was prepared and the fresh sample of the developed product was analysed for antioxidants analysis. Each analysis was performed in triplicates, the product was found rich in vitamin $\mathrm{E}(3.97 \pm 0.26 \mathrm{mg} / 100 \mathrm{~g})$, vitamin $C(107.58 \pm 0.21 \mathrm{mg} / 100 \mathrm{~g}), \beta$-carotene $(3.80 \pm 0.06 \mathrm{mg} / 100 \mathrm{~g})$ and flavonoid content $(840.00 \pm 7.00 \mathrm{mgQE} / 100 \mathrm{~g})$. The antioxidant activity was $55.07 \pm 0.24 \%$ (Table 2 ).

\section{Microbial quality}

The microbial quality in terms of total bacterial count and total fungal count were analyzed in fresh product. The mean total bacterial count in freshly prepared chutney was $0.421 \times 10^{4} \pm 5.57 \mathrm{cfu} / \mathrm{g}$ while the total fungal count was $0.98 \times 10^{2} \pm 5.56 \mathrm{cfu} / \mathrm{g}$ (Table 4).

\section{Shelf life study of the product}

To check the shelf life of the standardized product, the chilli garlic chutney was prepared in a lot and divided into $10 \mathrm{~g}$ portions and packed into zip lock bags and stored in deep freezing conditions $\left(0^{0} \mathrm{C}\right)$. The products were again analysed for all the parameters of food quality after 15 days and 30 days of storage.

\section{Sensory quality}

The mean sensory scores for all attributes were not changed significantly till 15 th day of storage which shows that the product was found acceptable with good sensory scores. Sensory quality assessed on 30th day of storage showed significant difference from day 1 but non-significant difference from the scores of day 15th for appearance, taste, and overall acceptability whereas significant difference for colour, consistency and flavour. Though the sensory scores have decreased 
with increasing duration of storage but the score obtained till 30 days of storage were in the good range rated as above 4 which shows the sensory quality of the product between good and very good (Table 1). It means the sensory quality of developed chutney was acceptable during the entire period of storage. In the present study the mean scores for attributes of sensory quality were slightly decreased during storage. The reduction in the sensory scores during storage may be attributed to the physico-chemical changes of chilli-garlic chutney. Decrease in colour may be due to decrease of lycopene content of tomato reported by Rao et al., (2011) on storage of tomato, which is major ingredient for colour contributor to the product. The decrease in the scores for consistency may be due to sublimation of the ingredients on law temperature.

Table.1 Effect of storage on sensory quality of chilli garlic chutney

\begin{tabular}{|c|c|c|c|c|c|c|}
\hline $\begin{array}{l}\text { Storage } \\
\text { period }\end{array}$ & Colour & Consistency & Appearance & Taste & Flavour & $\begin{array}{l}\text { Overall } \\
\text { acceptability }\end{array}$ \\
\hline Day $1^{\text {st }}$ & $4.46 \pm 0.20$ & $4.73 \pm 0.17$ & $4.50 \pm 0.18$ & $4.75 \pm 0.15$ & $4.58 \pm 0.20$ & $4.71 \pm 0.21$ \\
\hline Day $15^{\text {th }}$ & $4.31 \pm 0.16$ & $4.58 \pm 0.25$ & $4.35 \pm 0.23$ & $4.62 \pm 0.22$ & $4.43 \pm 0.19$ & $4.56 \pm 0.21$ \\
\hline Day 30 ${ }^{\text {th }}$ & $4.22 \pm 0.18$ & $4.34 \pm 0.21$ & $4.21 \pm 0.20$ & $4.48 \pm 0.18$ & $4.22 \pm 0.14$ & $4.42 \pm 0.17$ \\
\hline CD5\% & 0.173 & 0.198 & 0.193 & 0.175 & 0.167 & 0.186 \\
\hline
\end{tabular}

Table.2 Antioxidant contents and antioxidant activity in raw ingredients and fresh product

\begin{tabular}{|c|c|c|c|c|c|}
\hline Ingredients & $\begin{array}{c}\text { Vitamin } \mathbf{E} \\
\mathbf{m g} / \mathbf{1 0 0 g}\end{array}$ & $\begin{array}{c}\text { Vitamin C } \\
\mathbf{m g} / \mathbf{1 0 0 g}\end{array}$ & $\begin{array}{c}\boldsymbol{\beta} \text {-carotene } \\
\mathbf{m g} / \mathbf{1 0 0 g}\end{array}$ & $\begin{array}{c}\text { Flavonoids } \\
\mathbf{m g Q E} / \mathbf{1 0 0 g}\end{array}$ & $\begin{array}{c}\text { Antioxidant } \\
\text { activity (Per cent } \\
\text { Inhibition ) }\end{array}$ \\
\hline Dry red chilli & $34.25 \pm 1.59$ & $123.53 \pm 1.00$ & $6.18 \pm 0.24$ & $1902.40 \pm 1.95$ & $57.14 \pm 4.67$ \\
\hline Garlic & $1.35 \pm 0.01$ & $21.32 \pm 1.20$ & $\mathrm{~N} \mathrm{D}^{*}$ & $125 \pm 0.42$ & $18.68 \pm 1.48$ \\
\hline Coriander seeds & $1.85 \pm 0.03$ & $\mathrm{~N} \mathrm{D*}$ & $0.08 \pm 0.01$ & $1730 \pm 13.52$ & $66.48 \pm 1.29$ \\
\hline Tomato & $\mathrm{N} \mathrm{D}^{*}$ & $160.27 \pm 2.34$ & $5.50 \pm 0.41$ & $850 \pm 7.55$ & $65.38 \pm 1.35$ \\
\hline $\begin{array}{c}\text { Antioxidants in } \\
\text { fresh chutney }\end{array}$ & $3.97 \pm 0.26$ & $107.58 \pm 0.21$ & $3.80 \pm 0.06$ & $840.00 \pm 7.00$ & $55.07 \pm 0.24$ \\
\hline
\end{tabular}

N D*= Not detected

Table.3 Effect of storage on nutritional quality as assessed by antioxidant contents and antioxidant activity of chilli garlic chutney

\begin{tabular}{|c|c|c|c|c|c|}
\hline $\begin{array}{c}\text { Storage } \\
\text { period }\end{array}$ & $\begin{array}{c}\text { VitaminE } \\
\mathrm{mg} / 100 \mathrm{~g}\end{array}$ & Vitamin C mg/100g & $\begin{array}{c}\beta \text { C Carotene } \\
\mathrm{mg} / 100 \mathrm{~g}\end{array}$ & $\begin{array}{l}\text { Flavonoids } \\
\text { mgQE/100g }\end{array}$ & $\begin{array}{c}\text { Antioxidant } \\
\text { activity(Percen } \\
\text { Inhibition ) } \\
\end{array}$ \\
\hline Day $1^{\text {st }}$ & $3.97 \pm 0.26$ & $107.58 \pm 0.21$ & $3.80 \pm 0.06$ & $840.00 \pm 7.00$ & $55.07 \pm 0.24$ \\
\hline Day 15th & $3.90 \pm 0.24$ & $102.94 \pm 0.34$ & $3.40 \pm 0.13$ & $730.00 \pm 6.25$ & $54.43 \pm 1.48$ \\
\hline Day 30 ${ }^{\text {th }}$ & $2.79 \pm 0.10$ & $101.87 \pm 0.46$ & $3.40 \pm 0.04$ & $800.00 \pm 3.61$ & $54.20 \pm 0.28$ \\
\hline CD $5 \%$ & 0.422 & 0.706 & 0.169 & 11.593 & 1.756 \\
\hline
\end{tabular}

Table.4 Effect of storage period on microbial quality of chilli garlic chutney

\begin{tabular}{|l|c|c|}
\hline \multicolumn{1}{|c|}{ Treatment } & Total Bacterial count cfu/g & Total Fungal count cfu/g \\
\hline Day $\mathbf{~}^{\text {st }}$ & $0.421 \times 10^{4} \pm 5.57$ & $0.98 \times 10^{2} \pm 5.56$ \\
\hline Day 15th & $0.757 \times 10^{3} \pm 2.64$ & $0.94 \times 10^{2} \pm 4.58$ \\
\hline Day 30 & $0.543 \times 10^{3} \pm 18.02$ & $0.36 \times 10^{2} \pm 6.55$ \\
\hline CD 5\% & 21.97 & 11.24 \\
\hline
\end{tabular}


The mean scores of taste decreased due decrease in saltiness as increase of sourness due to tomato with passes of storage period. The flavor of the product may be influenced by the volatile nature of the spices. Maity and Raju, (2015) developed a ready to use tomato rasam paste and reported that all scores for sensory attributes of the paste were decreased during storage for four month at ambient temperature (28 and $37{ }^{\circ} \mathrm{C}$ ) and it was fairly acceptable even after storage of four months sensory stability in their product was due to hurdle processing. Rao et al., (2012) claimed good sensory acceptability of instant pulihora mix (IPM) even after a storage period of six months.

\section{Nutitional quality (as assessed by antioxidant contents and antioxidant activity)}

The significant loss of vitamin $\mathrm{C}$, and flavonoid content accrued with increasing the storage period (Table 3 ). The $\beta$ carotene content was decreased significantly when assessed on day 15 th and after day 15 th it was decreased non significantly. The vitamin $\mathrm{E}$ content of the stored chutney was not decreased significantly up to 15 th day of storage whereas after 15 days the vitamin E was decreased significantly. The antioxidant activity of the product was decreased during the storage period but the difference was not significant. Though the antioxidants of the product were decreased during storage period but the product contained considerable amount of antioxidants till end of the storage period. The loss in the vitamin $\mathrm{C}$ during storage could be due to thawing effect which degrades part of the vitamin $\mathrm{C}$ content, Yadla and Sachdev (2013) reported significant decrease of vitamin $\mathrm{C}, \quad \beta$ carotene and antioxidant activity in tomato salsa product under refrigerated $\left(4-10^{\circ} \mathrm{C}\right)$ conditions during storage.

\section{Microbial quality}

In view of the microbiological analysis of the stored chutney samples, it was observed that all the samples of chilli garlic chutney were contaminated with some extent of bacterial and fungal but within the acceptable limits (Anonymous, 2012). The effect of storage duration showed that total bacterial count and fungal count were drastically decreased from day 1 to 15 days of storage (Table 4). After 15 days of storage, the bacterial counts were again found decreased and the difference was also non significant whereas, the total fungal were decreased significantly. The chilly garlic chutney showed reduction in total bacteria and total fungus (yeast and mold) population. The reduction in microbial growth might be due to the inhibitory effect of spices and tomato towards microorganisms (Skrinjar and Nemet 2009). Fatima et al., (2015) reported that cold storage of tomato inhibit the growth and developments of pathogens and spoilage microorganisms. Yadla and Sachdev, (2013) reported the shelf-life of fresh tomato salsa was 1 week at room temperature $\left(28-30^{\circ} \mathrm{C}\right)$ and 2 months at refrigeration temperature $\left(4-10{ }^{\circ} \mathrm{C}\right)$. The good shelf life of dry fruit chutney for about 10-15 days if kept in air tight container in refrigerator was also reported by Shah and Sengupta (2014).

\section{References}

Ahamad, M.N., Saleemullah, M., Shah, H.U., Khalil, I.A. and Saljoqi, A.U.R. 2007. Determination of beta carotene content in fresh vegetables using high performance liquid chromatography. Sarhad J. Agri., 23(3): 67-70.

Anonymous. FSSAI. 2012.

Chandra, S., Khan, S., Avula, B., Lata, H., Yang, M.H., Elsohly, M.A. and Khan, IA. 2014. Assessment of total phenolic and flavonoid content, antioxidant properties and yield of aeroponically and conventionally grown leafy vegetables and fruit crops: a comparative study. Evidence-Based Complementary and Alternative Med., pp. 1-9.

Fatima, D., Mebrouk, K. and Miloud, H.2007. Biopreservation of tomato paste and 
sauce with Leuconostoc spp. metabolites. African J. Food Sci., 9(6):359-366

Jitbunjerdkul, S. and Kijroongrojana, K. 2007. Formulation of Thai herbal Namprik. Songkanakarin. J. Sci. Technol., 29(3): 837-846.

Juárez, L.A.M., Quijada, D.M.A.M., Sánchez, C.L.D.T., Aguilar, C.A.G. and Meza, N.G. 2012. Antioxidant activity of peppers (Capsicum annuuml.) extracts and characterization of their phenolic constituents. Interciencia, 37(8): 588-593.

Maity, T. and Raju, P.S. 2015. Development of shelf stable tomato rasam paste using hurdle technology. Int. Food Res. J., 22(1): 171-177.

Mandal, P. and Ghosal, M. 2012. Antioxidant activities of different parts of tree tomato fruit. Int. J. Pharmaceutical Sci., 13(2): 39-47.

Mitic, S.S., Kostic, D.A., Naskovicdokic, D.C. and Mitic, M.N. 2011. Rapid and reliable HPLC method for the determination of vitamin $\mathrm{C}$ in pharmaceutical samples. Trop J. Pharm. Res., 10(1): 105-111.

Nuutila, A.M., Puupponen-Pimia, R., Aarni, M., Oksman-Caldente, K.M. 2003. Comparison of antioxidant activities of onion and garlic extracts by inhibition of lipid per oxidation and radical scavenging activity. Food Chem., 81(4): 485-493

Oboh, G. 2005. Effect of blanching on the antioxidant property of some tropical green leafy vegetable. Food Sci. Tec., 38: 513-517.

Rachieru, D., Duca, R., Olteanu, M. 2009. Validation of a method to determine vitamin E (alpha-tocopherol) from feed ingredients by HPLC using reversed phased chromatography. Universitatea de Stiinte Agricolesi Medicina Veterinara Iasi Lucrari Stiintifice. 52: 543-547.

Rao, N., Rao, P.G., Balaswamy, P.G.K., Rao, D.G. 2011. Preparation of instant tomato pickle mix and evaluation of its storage stability. Int. Food Res. J., 18: 589-593

Rao, P.G.P., Rao, G.N., Nagender, A., Jyothirmayi, T., Satyanarayana, A. 2012. Standardization, chemical characterization and storage studies of an instant pulihora mix based on raw mango. Indian J. Traditional Knowledge, 11(1): 90-95.

Ruanma, K., Shank, L., Chairote, G. 2010. Phenolic content and antioxidant properties of green chilli paste and its ingredients. Maejo. Int. J. Sci. Technol., 4(1): 193-200.

Shah, K.J. and Sengupta, R. 2014. Dry fruit chutney. Int. J. Food and Nutritional Sci., 3(3):185-188

Silliker, J.H. 1963. Total counts as index of food quality. In: Microbiological quality of foods. L.W. slantez et al., (Ed) Academic Press, New York

Skrinjar, M.M., Nemet, N.T. 2009. BIBLID, 40: 195-209

Toor, R.K. and Savage, G.P. 2006. Effect of semi-drying on the antioxidant components of tomatoes. Food Chem., 94: 90-97.

Wangensteen, H., Samuelsen, A.B. and Malterud, K.E. 2004. Antioxidant activity in extracts from coriander. Food Chem., 88: 293-297

Yadla, A.K., Sachdev, P.A. 2013. Development of Fresh and Processed Tomato Salsa with Herbs. Scientific Reports, 2(3): 1-5.

\section{How to cite this article:}

Sumitra Kumari Meena, M. Agrawal, C.M. Balai and Jyoti Meena. 2017. Antioxidant Potential of Traditional Rajasthani Chilli Garlic Chutney and its Shelf Life. Int.J.Curr.Microbiol.App.Sci. 6(7): 3898-3904. doi: https://doi.org/10.20546/ijcmas.2017.607.402 